\title{
Effect of high forest and coppice regimes on the diameter distribution of Eucalyptus urophylla S. T. Blake stands
}

\author{
Efeito dos regimes de alto fuste e talhadia na distribuição diamétrica de \\ Eucalyptus urophylla S. T. Blake
}

\author{
Luani Rosa de Oliveira Piva' (D), Marieli Sabrina Ruza ${ }^{1}$ (D), Tatiane de Oliveira Heck² (D), \\ Ana Paula Dalla Corte ${ }^{1}$ [D, Sylvio Péllico Netto ${ }^{1}$ [D, Alexandre Behling ${ }^{1}$ (D) \\ ${ }^{1}$ Universidade Federal do Paraná - UFPR, Curitiba, PR, Brasil \\ ${ }^{2}$ Plantar Company, Curvelo, MG, Brasil
}

How to cite: Piva, L. R. O., Ruza, M. S., Heck, T. O., Dalla Corte, A. P., Péllico Netto, S., \& Behling, A. (2020). Effect of high forest and coppice regimes on the diameter distribution of Eucalyptus urophylla S. T. Blake stands. Scientia Forestalis, 48(127), e3224. https://doi.org/10.18671/scifor.v48n127.15

\begin{abstract}
Eucalyptus plantations in Brazil can be assigned to one of two management regimes; high forest and coppice. The characterization of the diameter distribution in plantations under different management regimes is important for making decisions regarding the optimal regime, and helps quantify numerous wood products. The aim of this study was to evaluate the diameter distribution of a Eucalyptus urophylla S. T. Blake stand in the State of Minas Gerais, Brazil, under different management regimes and ages. Specific probabilistic density functions for forest area were fitted, and a probability distribution proposed in the literature was selected to evaluate the effects of management regime and age on diameter distribution. In total, 7,113 trees in stands of three, five, and seven years were assessed. A total of 3,396 trees grew under a high forest regime and 3,710 under a coppice regime. The fitted distribution curve presents negative asymmetry according to the stand age. Regarding differences between regimes and ages, the distribution curve for high forest results in a diametric distribution with larger trees and highest frequency (number of trees), when compared to coppice, for the three ages evaluated. The growth in diameter under the high forest regime stagnated before the age of seven years, suggesting earlier clearcuts to be performed.
\end{abstract}

Keywords: Forest plantation; Probabilistic density functions; Growth; Age.

\section{Resumo}

Plantios de eucalipto são predominantemente conduzidos no Brasil por meio de dois regimes de manejo, alto fuste e talhadia. A caracterização da distribuição diamétrica de plantios sob diferentes regimes de manejo auxilia na tomada de decisão sobre o melhor regime a ser adotado, bem como na quantificação de multiprodutos madeireiros. O presente trabalho teve como objetivo avaliar a distribuição diamétrica de um povoamento de Eucalyptus urophylla S. T. Blake no Estado de Minas Gerais, sob diferentes regimes de manejo e idade. Funções de densidade probabilísticas específicas para a área florestal foram ajustadas, sendo que uma função proposta na literatura foi selecionada para avaliar os efeitos dos regimes de manejo e idade na distribuição diamétrica. Foram analisadas 7.113 árvores, sendo 3.396 do regime alto fuste e 3.710 do regime talhadia, contemplando as idades 3, 5 e 7 anos. Observou-se que, conforme a idade do povoamento, a curva de distribuição ajustada apresenta assimetria negativa. Ao avaliar as diferenças entre os regimes por idade, a curva de distribuição do regime alto fuste resulta em uma distribuição diamétrica com árvores de maior porte e com maior frequência (número de árvores),

Financial support: None.

Conflict of interest: Nothing to declare.

Corresponding author: marielisabrina93@gmail.com

Received: 18 December 2018.

Accepted: 6 September 2019.

Editor: Paulo Henrique Müller Silva. 
quando comparada ao regime talhadia, em todas as idades avaliadas. O crescimento em diâmetro no regime de alto fuste estagnou antes do sétimo ano, sugerindo a antecipação do corte raso.

Palavras-chave: Floresta plantada; Funções de densidade probabilística; Crescimento; Idade.

\section{INTRODUCTION}

The diameter distribution of forest stands can be affected by age as the distribution curve tends to flatten and move to the right (Bartoszeck et al., 2004). Populations of the genus Eucalyptus are grown in Brazil predominantly under two different management regimes: high forest and coppice. Under the high forest regime, also known as reforestation, harvesting if followed by planting of new plants, typically with the exchange of genetic material between the rows of the old plantation, which is a needed silvicultural measure (Scolforo \& Maestri 1998; Silva, 2013). The coppice regime is based on regrowth of the cut stems (Silva, 2013). This system was predominantly adopted during the first decades of cultivation of the genus Eucalyptus in Brazil due to the lower timber production costs (Lamprecht, 1990).

Under the coppice regime, the presence of an established root system facilitates the absorption of water and nutrients and the use of organic and inorganic reserves contained by stems and roots (Cacau et al., 2008; Teixeira et al., 2002). However, in an attempt to increase productivity, the high forest regime was adopted by forestry companies from the mid-1990s (Stape, 1997; Gonçalves et al., 2013). In 2009, coppicing accounted for $25 \%$ of the total eucalyptus area in Brazil, and this regime became an alternative mitigation for the global economic crisis of 2008 (Gonçalves et al., 2014).

The diameter distribution of forest stands can be used for assessing parameters including identification of differences of diameter structure between forest stands, range of diameter variation of the entire forest or of specific species, and forest growth, typically by using production tables that consider the dynamics of the forest population (Loetsch et al., 1973; Scolforo, 2006). Moreover, the diameter distribution is of great importance as a tool for management decision-making regarding the regime choice (Arce, 2005; Scolforo, 2006).

Diameter distributions allow for evaluating growth and production in the different classes of a forest and are typically based on probability density functions which are useful for evaluating thinning and the economic achievement with multiple products (Burkhart et al., 1981; Scolforo, 2006).

The aim of this study was to evaluate the effects of high forest and coppice management regimes on diameter distributions in clonal stands of Eucalyptus urophylla at different ages, based on probability density functions in order to provide information for forest management.

\section{MATERIAL AND METHODS}

\section{Study area}

Data was obtained from the continuous forest inventory of clonal stands of $E$. urophylla of the company Plantar, located near Felixlândia, state of Minas Gerais, Brazil.

The predominant soil in the region is the dystrophic Red-Yellow Latosol (dRYL), characterized by predominant Alayer and clayey texture (Fundação Estadual do Meio Ambiente, 2010). The relief is classified as smooth-wavy. The predominant climate type is Aw, a tropical zone with dry winters, with average annual precipitation from 1,300 to 1,600 mm, and average annual temperature is between 20 and $22^{\circ} \mathrm{C}$ (Alvarez et al., 2013).

Inventory data were collected in rectangular plots of different areas and with a fixed number of 60 pits. The plots were randomly allocated, and over-bark circumferences at 1.30 $m$ above-ground $(C B H)$ of all trees were measured within each plot using metric tape. One plot per ten hectares was installed, with at least two plots per stand. The plots were randomly selected using the ArcGis software and were allocated in field using GPS coordinates. 


\section{Number of trees and diameter class widths}

All the trees were of the same genotype and from a unique site quality, with plant spacing of $3.5 \times 2.6 \mathrm{~m}$. The plantations were managed under high forest or coppice regimes at ages of three, five, and seven years. Data from eight different stands (area ranging from 3.4 to 45.2 hectares) of each regime were analyzed.

In total, data of 7,113 trees were recorded, from which 3,396 were grown under a high forest regime and 3,710 under a coppice regime (Table 1). The diameter at breast high (DBH) ranged from 4.1 to $22.9 \mathrm{~cm}$ under the high forest regime. Under the coppice regime, the DBH ranged from 2.5 to $19.0 \mathrm{~cm}$.

Table 1. Number of trees by management regime, stand age and diametric amplitude of Eucalyptus urophylla trees.

\begin{tabular}{ccccc}
\hline Management regimes & Age (years) & $\boldsymbol{n}$ & $\boldsymbol{D B}_{\boldsymbol{m i n}}(\mathbf{c m})$ & $\boldsymbol{D B}_{\boldsymbol{m a x}}(\mathbf{c m})$ \\
\hline High forest & 3 & 1122 & 3.6 & 20.2 \\
High forest & 5 & 1060 & 4.6 & 24.5 \\
High forest & 7 & 1214 & 4.1 & 23.9 \\
Coppice & 3 & 1362 & 2.5 & 16.8 \\
Coppice & 5 & 1356 & 2.6 & 19.3 \\
Coppice & 7 & 992 & 2.6 & 21.0 \\
\hline
\end{tabular}

Where: $n$ is the total number of trees; $D B H_{\min }$ is the minimum diameter in centimeters; $D B H_{\max }$ is the maximum diameter, in centimeters.

The number of diameter classes was determined by the formula of Sturges (1926):

$n_{c}=1+3.322 \log _{10} n$

where $n_{c}$ is the number of classes and $n$ is the number of trees.

For all cases, the diameter class widths were obtained from the following equation:

$$
i_{c}=\frac{A}{n_{c}}
$$

where $i_{c}$ is the diameter class widths, $A$ is the amplitude, and $n_{c}$ is the number of classes.

\section{Probabilistic density functions}

The classical probabilistic density functions (pdf) Normal, Weibull, Exponential, LogNormal, Beta, Gamma (Johnson \& Kotz, 1970), and novel functions of Weber (2006), and Silva et al. (2003) were tested to estimate frequency distributions of trees by diameter classes. The pdf proposed by Silva et al. (2003) yielded the best fit to the sample data and was therefore applied. This pdf was developed and first applied to forest variables, specified as follows:

$$
\frac{1}{k}\left\{\begin{array}{c}
c_{1} x^{d} \text { if } 0<x<l_{1} \\
a_{1} x^{n}+a_{2} x^{n-1}+\ldots+a_{m} \quad \text { if } l_{1} \leq x \leq l_{2} \\
\frac{c_{2}}{x^{h}} \text { if } x>l_{2} \\
0 \text { e.o.c }
\end{array}\right.
$$


where $n, d$, and $h$ are positive integers; $a_{1}, a_{2}, \ldots a_{m}$, are real numbers; $c_{1}$ and $c_{2}$ are real numbers; $k$ is the value of the integral $\int_{0}^{\infty}\left[x^{d} c_{1}+\left(a_{1} x^{n}+a_{2} x^{n-1}+a_{3} x^{n-2}+\ldots+a_{m}\right)+\frac{c_{2}}{x^{h}}\right] d_{x} ; x$ is the variable; $l_{l}$ : upper limit of the class where the function $c_{1}{ }^{*} x^{d}, l_{2}$ : upper limit of the last class will be adjusted up to where the polynomial produces a good fit.

This polynomial distribution consists of three mathematical functions and is known as "truncated pdf" which shows great flexibility when fit to forest data (Silva et al., 2003). In this model, the first part consists of a positive potential increasing function and the second is a polynomial fit by the least-squares method. The third is a hyperbolic function with $y=0$ as an asymptote. The three functions must meet the assumptions of a pdf, that is, they must be continuous, with non-negative and convergent values in $(0,+\infty)$. Silva et al. (2003) emphasize that five steps are necessary to fit these functions, i.e.:

First step: fit a polynomial of a specified degree, identified as $g_{2}(x)$, which best represent the absolute frequencies observed;

Second step: produce a graph of the fitted polynomial in order to observe in which classes it assumes negative values or contradicts the tendency of the observed data. Here, classes should be disregarded;

Third step: for the classes identified in step two, the following functions should be fitted - for the first class the function is $g_{1}(x)=c_{1} x^{d}$ and for the last class the function $g_{3}(x)=c_{2} / x^{h}$.

Fourth step: combine the three functions defined previously: $g_{1}(x)=c_{1} x^{d}$, $g_{2}(x)=x^{n}+a_{2} x^{n-1}+a_{3} x^{n-2}+\ldots+a_{m}$. Subsequently, the result of the integral $\int_{0}^{\infty} g(x) d x$ must be calculated to obtain the value of $k$;

Fifth step: multiply the function $g(x)$ by $\frac{1}{k}$ to obtain a probability density function $f(x)$, where $\int_{0}^{\infty} f(x) d x=1$.

\section{Goodness of fit tests}

To verify the goodness of fit of the obtained probability density function, a KolmogorovSmirnov test was used at the $99 \%$ probability level.

$$
\begin{aligned}
& D_{n}=\frac{\max \left|F_{o}-F_{e}\right|}{n} \\
& D_{\text {critical }(\alpha=0,01)}=\frac{1.36}{\sqrt{n}}
\end{aligned}
$$

where $\mathrm{D}_{\mathrm{n}}$ is the diameter class widths, $\mathrm{F}_{\mathrm{o}}$ is the accumulated distribution observed, and $\mathrm{F}_{\mathrm{e}}$ is the estimated cumulative distribution.

\section{Evaluation of the diameter distribution}

The analyses of management regimes and ages were performed applying the probability distribution determined by Silva et al. (2003), to test the respective effects on diameter distributions.

Subsequently, the diameter distribution was subdivided into the following three classes, to produce a percentage estimation of a forest multiproduct:

Class 1: trees with $\mathrm{DBH}<8 \mathrm{~cm}$;

Class 2: trees with $8 \mathrm{~cm} \leq \mathrm{DBH}<12 \mathrm{~cm}$;

Class 3: trees with $\mathrm{DBH} \geq 12 \mathrm{~cm}$.

The integrals of each fitted function were calculated using the function $\int_{0}^{\infty} g(x) d x$ to obtain the total area under the respective curve. Subsequently, the proportion of the integral area of each class was estimated in relative values from the total result of the integration, indicating the proportion of trees in the stand distributed in the three diameter classes (Figure 1). 


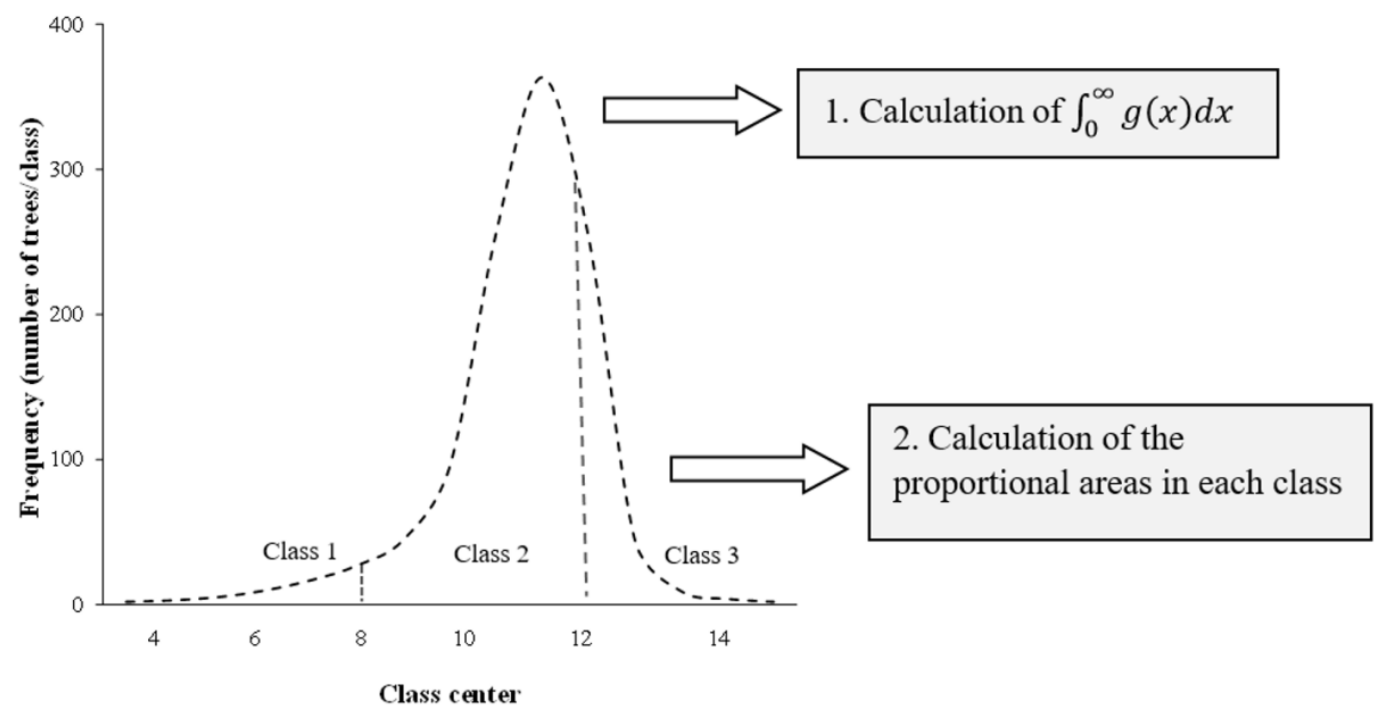

Figure 1. Procedure for calculating the integral of the curve and the relative proportions of the areas corresponding to each assortment class, performed for each estimated distribution curve.

\section{RESULTS AND DISCUSSION}

Goodness of fit to all different management regimes and ages analyzed was tested using a Kolmogorov-Smirnov test (Table 2).

Table 2. Results of the Kolmogorov-Smirnov goodness of fit test for different management regimes and ages in a plantation of Eucalyptus urophylla, Minas Gerais, Brazil.

\begin{tabular}{ccccc}
\hline $\begin{array}{c}\text { Probability } \\
\text { distribution }\end{array}$ & Management regime & Age (years) & $\begin{array}{c}\text { Kolmogorov- } \\
\text { Smirnov (D) }\end{array}$ & D calculated (99\%) \\
\hline & Coppice & 3 & 0.0369 & $0.0110^{\text {ns }}$ \\
Silva et al. & Coppice & 5 & 0.0369 & $0.0185^{\text {ns }}$ \\
$(2003)$ & Coppice & 7 & 0.0432 & $0.0093^{\text {ns }}$ \\
& High forest & 3 & 0.0406 & $0.0068^{\text {ns }}$ \\
& High forest & 5 & 0.0412 & $0.0089^{\text {ns }}$ \\
& High forest & 7 & 0.0389 & $0.0033^{\text {ns }}$ \\
\hline
\end{tabular}

The probability distribution determined by Silva et al. (2003) has been applied in few studies so far. For example, Ebling \& Péllico Netto (2015) used this function for diameter distribution of Araucaria angustifolia to assess bi-modal distributions in cohorts in Southern Brazil. It is worth noting that the application of Silva's function to diametric distributions in forest stands begins to be competitive when compared to other functions of expressive use by the international scientific community, such as Weibull, Normal, Gamma, Beta and others.

The probability distribution determined by Silva et al. (2003) was developed for application on tree variables of natural forests, and it can be extended to stands and conditions in which the traditional models do not attain sufficient goodness of fit. The calculated coefficients are shown below:

\section{Coppice, 3 years}




$$
f(x)=\frac{1}{898.9204}\left\{\begin{array}{c}
2.69322 x^{2.19} \text { if } 0<x<5.06 \\
9.19446 x^{5}-309.11534 x^{4}+4087.70082 x^{3}-26603.97139 x^{2}+ \\
85382.19180 x-108221.58058 \text { if } 5.06 \leq x \leq 8.98 \\
\frac{1.62254 E+39}{x^{39.38}} \text { if } x>8.98 \\
\text { o e.o.c }
\end{array}\right.
$$

Coppice, 5 years

$$
f(x)=\frac{1}{1068.4822}\left\{\begin{array}{c}
4.03619 x^{1.81} \text { if } 0<x<7.06 \\
-42.03661 x^{3}+1022.29246 x^{2}-8166.0397 x+ \\
21627.29361 \text { if } 7.06 \leq x \leq 10.09 \\
\frac{5.03294 E+30}{x^{28.48}} \text { if } x>10.09 \\
\text { o e.o.c }
\end{array}\right.
$$

\section{Coppice, 7 years}

$$
f(x)=\frac{1}{839.4439}\left\{\begin{array}{c}
0.47892 x^{2.56} \text { if } 0<x<6.72 \\
-4.95456 x^{4}+154.03331 x^{3}-1767.45235 x^{2}+ \\
8925.10335 x-16737.83809 \quad \text { if } 6.72 \leq x \leq 10.91 \\
\frac{2.22809 E+40}{x^{36.99}} \text { if } x>10.91 \\
\text { o e.o.c }
\end{array}\right.
$$

High forest, 3 years

$$
f(x)=\frac{1}{838.4289}\left\{\begin{array}{c}
0.007172 x^{4.37} \text { if } 0<x<7.38 \\
-63.51140 x^{3}+1645.78085 x^{2}- \\
13990.45316 x+39185,81399 \text { if } 7.38 \leq x \leq 10.40 \\
\frac{3.30411 E+27}{x^{24.70}} \text { if } x>10.40 \\
\text { 0 e.o.c }
\end{array}\right.
$$

High forest, 5 years

$$
f(x)=\frac{1}{944.1114}\left\{\begin{array}{c}
2.2075 E-5 x^{6.94} \text { if } 0<x<10.42 \\
-158.72971 x^{2}+3541.42509 x-19413.93810 \\
\text { if } 10.42 \leq x \leq 12.22 \\
\frac{9.94505 E+27}{x^{23.73}} \text { if } x>12.22 \\
0 \text { e.o.c }
\end{array}\right.
$$

High forest, 7 years

$$
f(x)=\frac{1}{1060.6945}\left\{\begin{array}{lr}
7.9666 E-8 x^{9.38} & \text { if } 0<x<10.17 \\
-114.19753 x^{2}+2589.77486 x-14304.42204 & \text { if } 10.17 \leq x \leq 11.97 \\
\frac{1.16992 E+22}{x^{18.13}} & \text { if } x>11.97 \\
0 & \text { e. } 0 . c
\end{array}\right.
$$


In the coppice regime distributions, goodness of fit of the polynomial curves for the observed frequencies was obtained for all considered ages (Figure 2). The class centers ranged from 3.1 to $11.7 \mathrm{~cm}$, which was smaller than the ones from the high forest regime (4.3 to 14 $\mathrm{cm})$. Seven-year old stands presented higher classes as the most frequent, when compared to five-year old and three-year old stands (the $10.1 \mathrm{~cm}$ class was most frequent). Also, the fiveyears old stands had higher classes as the most frequent than three-years old stands (the class of $9.3 \mathrm{~cm}$ was the most frequent), showing that older stands have a diametric distribution with larger trees. Accordingly, the adjusted of probability distribution determined by Silva et al. (2003) showed negative asymmetry, which accurately described the characteristics of each stand, thus producing a good fit for all examined ages.

The frequency distributions of the three and five year age classes showed a tendency to normality (three years) and slightly negative asymmetry (five years) (Figures $2 a$ and 2b). At the age of seven years, there was a stronger tendency to negative asymmetry, and the adjusted probability distribution determined by Silva et al. (2003) underestimated the frequency in the two larger diameter classes (Figure 2c). This trend indicates that, at the age of seven years under the coppice regime, trees with larger diameters predominate and thinner trees are less common, which may indicate the optimal time for harvesting. Eucalyptus trees in stands for energy production should have a tip diameter below $8 \mathrm{~cm}$ (Couto \& Bastos, 1987; Mendonça et al., 2014)

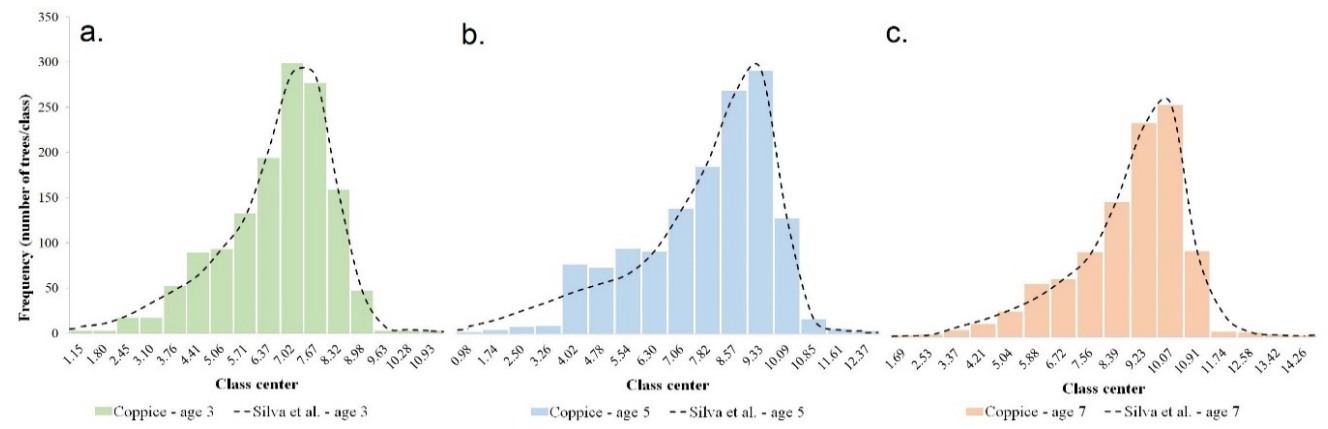

Figure 2. Tracing of lines according to the observed frequency histogram for the ages three (a), five (b), and seven years (c), under a coppice management regime for Eucalyptus urophylla, Minas Gerais, Brazil.

Furthermore, a good fit of probability distribution determined by Silva et al. (2003) was observed under the high forest regime (Figure 3). Minor differences of diameter distributions were observed in five-year and seven-year old stands of the high forest regime.The fact that the value of the most frequent class for the age five years was higher than the value found for the age of seven years, is an indicator for the decision-making usually adopted by companies in plantations of eucalyptus for energy purposes, an age range in which harvesting are usually made (Gonçalves et al., 2014). Also, we observed tendencies of underestimation in the adjusted distributions for the observed frequencies for all evaluated ages.

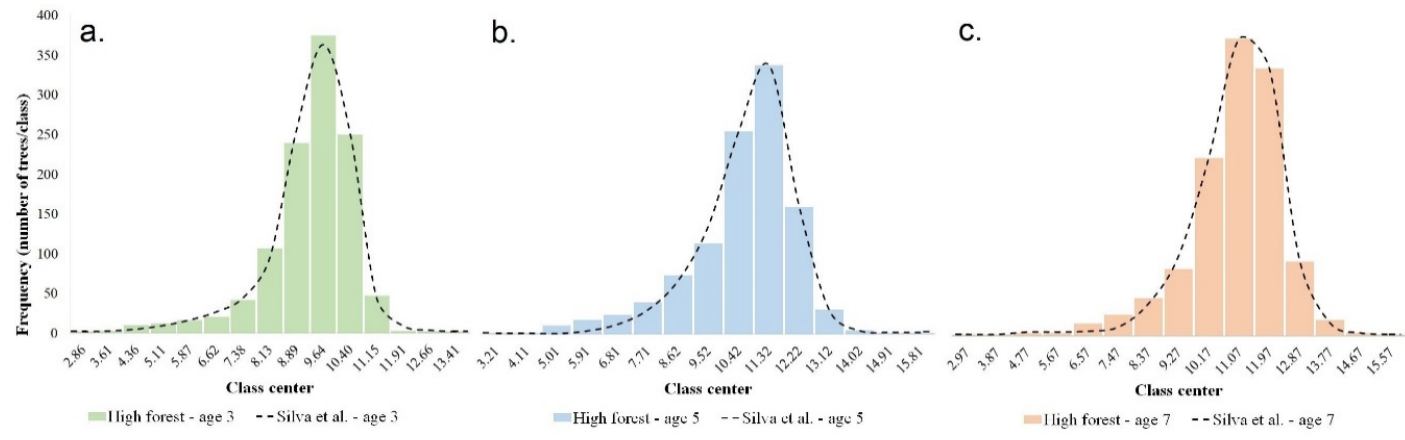

Figure 3. Tracing of lines according to the observed frequency histogram for the ages three (a), five (b), and seven years (c), under a high forest management regime for Eucalyptus urophylla, Minas Gerais, Brazil. 
Trees of the high forest regime showed DBH values from 3.60 to $24.45 \mathrm{~cm}$, and the diameters of the most frequent class were larger than that of trees under the coppice regime. There, the DBH values were $2.45 \mathrm{~cm}$ to $21.00 \mathrm{~cm}$.

Sousa et al. (2013) examined 5-year-old E. urophylla stands under coppice and high forest management regimes and found little variation in DBH values (8.69 to $16.87 \mathrm{~cm}$ under the high forest regime and 6.21 to $15.25 \mathrm{~cm}$ under the coppice regime), indicating that growth did not differ substantially between the regimes. Gonçalves et al. (2014) analyzed E. grandis x urophylla hybrid plantations in six different municipalities in Bahia and found that the productivity of plantations was influenced by the amount of available water, and that in areas with higher rainfall the productivity of the coppice regime was higher than that of the high forest regime.

The coppice regime has been adopted by several forestry companies and, in some cases, plantation costs were reduced by $50 \%$, but some researchers found a reduction in wood productivity. Chaves \& Marrichi (2015) and Almado (2015) reported a reduction of wood productivity by about $10 \%$ in the second rotation, while Silva (2016) found a reduction by up to $78 \%$ from the first to the second rotation, which is in line with the results presented above. Moreover, the coppice regime is advantageous because of the lower usage of fertilizers and water which helps to conserve the soil (Chaves \& Marrichi, 2015; Hakamada et al., 2015).

In the distributions fitted for the different ages and management regimes we observed that a negative asymmetry in the frequency distributions occurred as population age increased (Figures 4 and 5), corroborating the results of Bartoszeck et al. (2004).
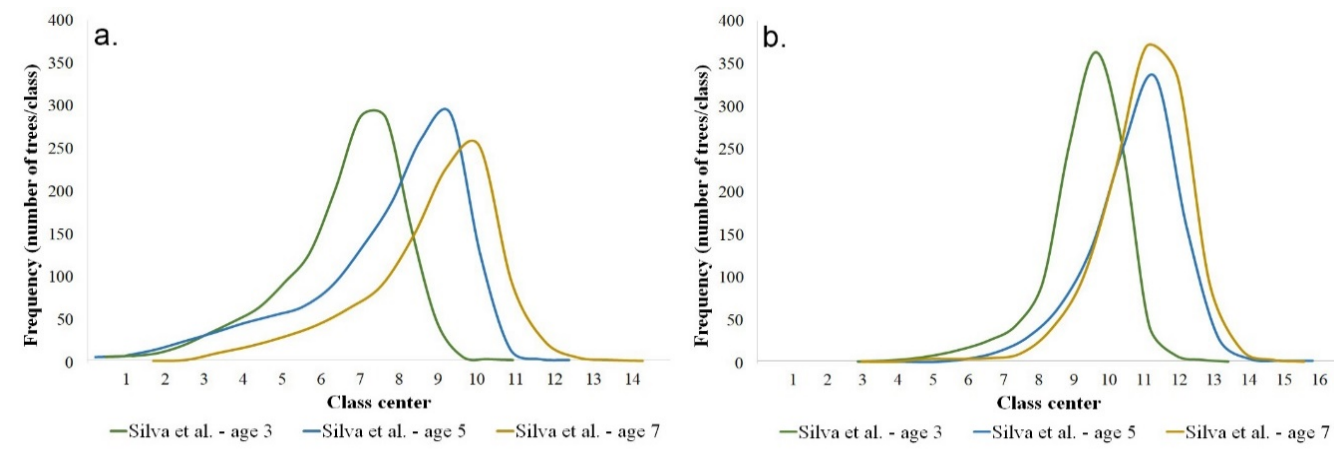

Figure 4. Probability density functions at ages three (green), five (blue) and seven years (orange), for the coppice (a) and high forest (b) regimes for Eucalyptus urophylla, Minas Gerais, Brazil.
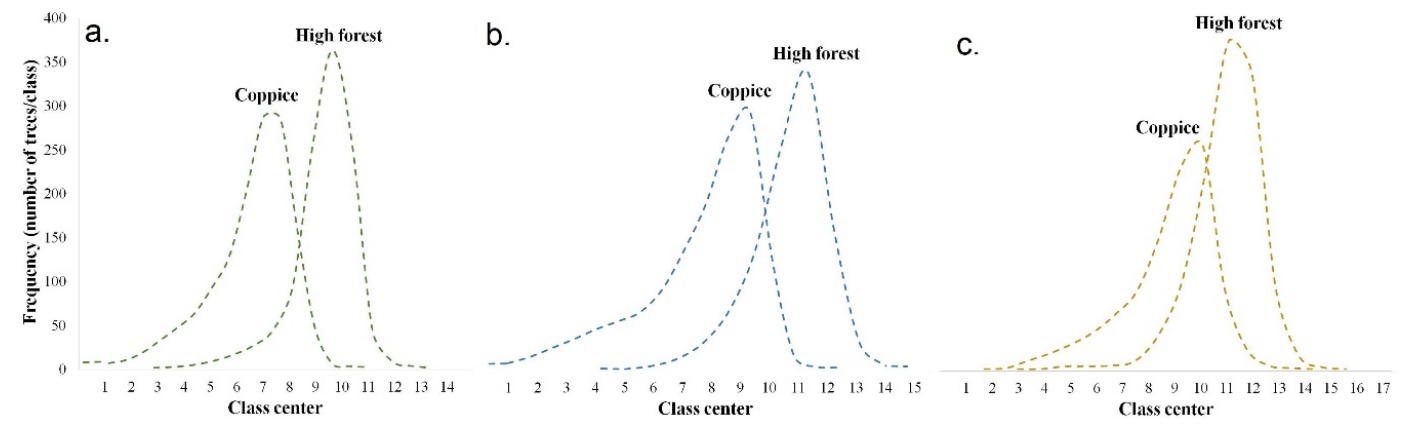

Figure 5. Comparison between the fitted curves of coppice and high forest regimes for the ages three (a), five (b) and seven years (c) for Eucalyptus urophylla, Minas Gerais, Brazil.

Moreover, the curves of the coppice regime presented negative asymmetry with increasing age. However, there was a gradual reduction of tree frequencies between the ages of five and sevenyears.

Under the high forest regime, the curves stabilized between ages of five and seven years, showing a tendency of DBH stagnation and indicating that harvesting can be performed 
before the age of seven years; however, no respective analysis of optimal harvest age was performed in the present study.

Regarding differences between ages in both management regimes, the distribution curves of the high forest were positioned to the right of those of the coppice curves, and showed a stronger effect of age. The difference between ages was minimal at the age of five years when the coppice regime curves was similar to the distribution at the age of three years. The most pronounced difference between distribution curves was observed at the age of seven years, as DBH growth is stabilized at this age under the high forest regime, and the curve concentrates higher frequencies in a smaller number of classes compared to the frequencies observed at the age of five years. Under the coppice regime, the amplitude of the distribution increased because the trees were still growing. The calculated probabilities $(P)$ of the fitted distributions for each assortment class are shown in Table 3.

Table 3. Area proportion under the curve for the three assortment classes, for coppice and high forest regimes, for Eucalyptus urophylla, Minas Gerais, Brazil.

\begin{tabular}{ccccc}
\hline Management & Age & Class 1 (4-8 cm) & Class 2 (8-12 cm) & Class 3 (>12 cm) \\
\cline { 3 - 5 } Regime & (Years) & P (\%) & P (\%) & P (\%) \\
\hline Coppice & 3 & 16.5 & 37.8 & 45.6 \\
Coppice & 5 & 16.4 & 16.0 & 67.6 \\
Coppice & 7 & 5.1 & 16.6 & 78.3 \\
High Forest & 3 & 2.2 & 10.1 & 87.8 \\
High Forest & 5 & 0.4 & 2.8 & 96.8 \\
High Forest & 7 & 0.2 & 1.5 & 98.3 \\
\hline
\end{tabular}

Under all conditions, the class 3 (trees with diameter> $12 \mathrm{~cm}$ ) presented greater percentage values for the area under the fitted distributions. However, the proportional values differed less between the three classes under the coppice regime. There, the values of class 2 and 3 differed less at the age of three years. Regarding the high forest regime, more than $85 \%$ of the areas of the fitted distributions originated from class 3, corroborating the visual analysis, in which a minor part of the distribution included trees with diameters between 4 and $12 \mathrm{~cm}$.

The proportional areas under the curves fitted according to assortment classes indicated the diameter classes with the largest number of trees. On average, $64 \%$ of the trees under the coppice regime and $94 \%$ of the trees under the high forest regime had diameters larger than $12 \mathrm{~cm}$. This information may be useful for forest management regarding decisions on commercial use of produced wood, which may help to increase profit margins.

\section{CONCLUSIONS}

- The probability distribution proposed by Silva et al. (2003) is appropriate for describing the diameter distributions at different ages and management regimes of $E$. urophylla stands in Minas Gerais, Brazil, verified by the adherence detected by the KolmogorovSmirnov test.

- The diameter distributions differed between the two management regimes. Diameter growth stagnated before the age of seven years under the high forest regime, suggesting earlier clear-cuts. Under the coppice regime, harvesting is recommended at seven years of age. Moreover, in spite of the fact that the high forest regime incurred in higher operational costs; it results in a diametric distribution with larger trees than that obtained in the coppice regime, for the three ages evaluated.

\section{ACKNOWLEDGEMENTS}

The authors are grateful to Plantar Company for supplying the forest inventory data used in this study. The authors are also grateful to CAPES and CNPq for granting the scholarships that supported this study. 


\section{REFERENCES}

Almado, R. P. (2015). Manejo de brotação em áreas da ArcelorMittal BioFlorestas Ltda (Série Técnica IPEF, Vol. 21, No. 42). Piracicaba: IPEF.

Alvarez, C. A., Stape, J. L., Sentelhas, P. C., Gonçalves, J. L. M., \& Sparovek, G. (2013). Köppen'sclimateclassificationmap for Brasil. Meteorologische Zeitschrift, 22(6), 711-728.

Arce, J. E. (2005). Modelagem da estrutura de florestas clonais de Populus deltoidesmarsh. através de distribuições diamétricas probabilísticas. Ciência Florestal, 14(1), 149-164. http://dx.doi.org/10.5902/198050981790.

Bartoszeck, A., Machado, S. D. A., Figueiredo Filho, A., \& Oliveira, E. B. (2004). A distribuição diamétrica para bracatingais em diferentes idades, sítios e densidades na região metropolitana de Curitiba. Floresta, 34(3), 305-323. http://dx.doi.org/10.5380/rf.v34i3.2418.

Burkhart, H. E., Cao, Q. V., \& Ware, K. D. (1981). A comparison of growth and yeldprdiction models for loblolly pine (59 p.). Blacksburg: Virginia Polytechnic Institute and State University, Scholl of Forestry and Wildlife Resources.

Cacau, F. V., Reis, G. G., Reis, M. G. F., Leite, H. G., Alves, F. F., \& Souza, F. C. (2008). Decepa de plantas jovens de Eucalipto e manejo de brotações em um Sistema Agroflorestal. Pesquisa Agropecuária Brasileira, 43(11), 1457-1465. http://dx.doi.org/10.1590/S0100-204X2008001100003.

Chaves, R, \& Marrichi, A. H. C. (2015). Manejo de talhadia (2 ${ }^{a}$ Rotação) na Duratex (Série Técnica IPEF, Vol. 21, No. 42). Piracicaba: IPEF.

Couto, H. T. Z., \& Bastos, N. L. M. (1987). Modelos de equações de volume e relações hipsométricas para plantações de Eucalyptus no Estado de São Paulo. Revista Ipef, 37, 33-44.

Ebling, A. A., \& Péllico Netto, S. (2015). Modelagem de ocorrência de coortes na estrutura diamétrica da Araucariaangustifolia (bertol.) Kuntze. Cerne, 21(2), 251-257. http://dx.doi.org/10.1590/01047760201521111667.

Fundação Estadual do Meio Ambiente. (2010). Mapa de solos de Minas Gerais: legenda expandida (49 p.). Belo Horizonte: Fundação Estadual do Meio Ambiente/UFV/CETEC/UFLA/FEAM.

Gonçalves, J. L. M., Alvares, C. A., Behling, M., Alves, J. M., Pizzi, G. T., \& Angeli, A. (2014). Produtividade de plantações de eucalipto manejadas os sistemas de lto fuste e talhadia, em função de fatores edafoclimáticos. Scientia Forestalis, 42(103), 411-419.

Gonçalves, J. L. M., Alvares, C. A., Higa, A. R., Silva, L. D., Alfenas, A. C., Stahl, J., Ferraz, S. F. B., Lima, W. P., Brancalion, P. H. S., Hubner, A., Bouillet, J. P. D., Laclau, J. P., Nouvellon, Y., \& Epron, D. (2013). Integrating genetic and silvicultural strategies to minimize abiotic and biotic constraints in Brazilian eucalypt plantations. Forest Ecology and Management, 301, 6-27. http://dx.doi.org/10.1016/j.foreco.2012.12.030.

Hakamada, R. E., Lemos, C. C. Z., Batistuzzo, G. Z. B., Silva, R. M. L., \& Almeida, A. E. A. (2015). Uso do inventario florestal para identificação de fatores silviculturais e ambientais que afetam a produtividade de Eucalyptus manejado sob talhadia (Série Técnica IPEF, Vol. 21, No. 42). Piracicaba: IPEF.

Johnson, N. L., \& Kotz, S. (1970). Continuousunivariate distributions-1 (300 p.). Boston: Houghton Mifflin Co.

Lamprecht, H. (1990). Silvicultura nos trópicos (343 p.). Eschborn: GTZ.

Loetsch, F., Zoehrer, F., \& Haller, K. E. (1973). Forest Inventory (469 p.). Berlin: BLV Verlag.

Mendonça, A. R., Calegario, N., Silva, G. F., Souza, A. L., Trugilho, P. F., Carvalho, S. P. C., \& Possato, E. L. (2014). Modelagem da produção de sortimentos em povoamentos de eucalipto. Cerne, 20(4), 587594. http://dx.doi.org/10.1590/01047760201420041366.

Scolforo, J. R. S. (2006). Biometria Florestal: modelos de crescimento e produção florestal (393 p.). Lavras: UFLA/FAEPE.

Scolforo, J. R., \& Maestri, R. (1998). O manejo de florestas plantadas. In J. R. S. Scolforo (Ed.), Manejo florestal (438 p.). Lavras: UFLA/FAEPE.

Silva, E. Q., Péllico Netto, S. P., Machado, S. A., \& Sanquetta, C. R. (2003). Função densidade de probabilidade aplicável à Ciência Florestal. Revista Floresta, 33(3), 285-294. http://dx.doi.org/10.5380/rf.v33i3.2262.

Silva, J. A. A. (2016). Potencialidade de florestas energéticas de rápido crescimento no bioma caatinga. In Anais do I Simpósio do Bioma Caatinga (pp. 117-124). Petrolina: Embrapa Semiárido.

Silva, N. F. (2013). Produtividade, demanda e eficiência nutricional de clones de eucalipto em regime de alto fuste e talhadia (Dissertação de mestrado). Universidade Federal de Viçosa, Viçosa. 
Sousa, G. T. O., Azevedo, G. B., Barreto, P. A. B., \& Júnior, V. C. (2013). Relações hipsométricas para Eucalyptus urophylla conduzidos sob regime de alto fuste e talhadia no Sudoeste da Bahia. Scientia Plena, 9(4), 1-7.

Stape, J. L. (1997). Planejamento global e normatização de procedimentos operacionais da talhadia simples em Eucalyptus. Série Técnica IPEF, 11(30), 51-62.

Sturges, H. A. (1926). The choice of a class interval. Journal of the American Statistical Association, 21(153), 65-66. http://dx.doi.org/10.1080/01621459.1926.10502161.

Teixeira, P. C., Novais, R. F., Barros, N. F., Neves, J. C. L., \& Teixeira, J. L. (2002). Eucalyptus urophylla root growth, stem sprouting and nutrient supply from the roots and soil. Forest Ecology and Management, 160(1-3), 263-271. http://dx.doi.org/10.1016/S0378-1127(01)00469-8.

Weber, S. H. (2006). Desenvolvimento de nova função densidade de probabilidade para avaliação de regeneração natural (Dissertação de mestrado). Universidade Federal do Paraná, Curitiba.

Authors' contributions: LROP and MSR: conceptualization, data curation, formal analysis, methodology, validation, writing; TOH: conceptualization, data curation, formal analysis, writing; APDC: conceptualization, methodology, supervision, writing; SPN and AB: conceptualization, data curation, methodology, supervision, validation, writing. 